\title{
Physicochemical Surface Properties \\ of Brewing Yeast Influencing Their \\ Immobilization Onto Spent Grains in a Continuous Reactor
}

\author{
Tomáš Brányik, António Vicente, Rosário Oliveira, José Teixeira \\ Centro de Engenharia Biológica, Universidade do Minho, Campus de Gualtar, \\ 4710-057 Braga, Portugal; telephone: +351-253-604406; \\ fax: +351-253-678986; e-mail: jateixeira@deb.uminho.pt
}

Received 19 August 2003; accepted 4 June 2004

Published online 9 September 2004 in Wiley InterScience (www.interscience.wiley.com). DOI: 10.1002/bit.20217

\begin{abstract}
Immobilization of brewing yeast onto a cellulosebased carrier obtained from spent grains, a brewing byproduct, by acid/base treatment has been studied in a continuously operating bubble-column reactor. The aim of this work was to study the mechanisms of brewing yeast immobilization onto spent grain particles through the information on physicochemical surface properties of brewing yeast and spent grain particles. Three mechanisms of brewing yeast immobilization onto spent grains carrier were proposed: cell-carrier adhesion, cell-cell attachment, and cell adsorption (accumulation) inside natural shelters (carrier's surface roughness). The possibility of stable cell-carrier adhesion regarding the free energy of interaction was proved and the relative importance of longrange forces (Derjaguin-Landau-Verwey-Overbeek theory) and interfacial free energies was discussed. As for the cell-cell attachment leading to a multilayer yeast immobilization, a physicochemical interaction through localized hydrophobic regions on cell surface was hypothesized. However, neither flocculation nor chain formation mechanism can be excluded so far. The adsorption of brewing yeast inside sufficiently large crevices (pores) was documented with photomicrographs. A positive effect of higher dilution rate and increased hydrophobicity of base-treated spent grains on the yeast immobilization rate has also been found. (c) 2004 Wiley Periodicals, Inc.

Keywords: brewing yeast; immobilization; spent grains; adhesion; hydrophobicity; Derjaguin-Landau-VerweyOverbeek theory
\end{abstract}

\section{INTRODUCTION}

Immobilization of microbial cells by retention on the surface of a solid porous or nonporous support material is a traditional immobilization method. While on porous carriers cells accumulate mainly due to steric retention, the prevailing interactions between cells and nonporous supports are considered to have physicochemical character (electrostatic, hydrophobic). Generally, an organism tends

Correspondence to: José Teixeira

Contract grant sponsor: Fundação para Ciência e Technologia

Contract grant number: SFRH/BPD/3541/2000 to adhere to solid surfaces to minimize the free energy of the system (Chamberlain, 1992). It should be stressed that in biological systems the hydrophobic attraction is not limited only to hydrophobic surfaces, but it is quite common also between a hydrophobic entity and a hydrophilic one immersed in water (van Oss, 1995). The advantages of cell adhesion to nonporous carriers consist in lower mass transfer limitation of substrates and products due to direct contact between cells and bulk liquid and also in the simplicity of the immobilization. The main risk of this method is the biofilm detachment induced by changes in cell environment (Mozes and Rouxhet, 1990).

The retention of a microorganism by a collecting surface (attachment, adhesion) and cell flocculation and agglomeration are terms used to describe the change from a dispersed cell suspension to an agglomerated state. Both the mechanism of formation of stable multicellular associations and that of a coherent cellular deposit on a solid surface have many features in common. In general, the mechanism leading to microbial aggregation starts when two cells approach each other. When long-range attractive forces (van der Waals) overcome electrostatic repulsive forces, a weak reversible attachment between cells is established as a result of a favorable energetic balance. Adhesion can be further intensified through short-distance forces as hydrophobic interactions, polar interactions, hydrogen bonds, and specific molecular interaction (Shankar and Umesh-Kumar, 1994; Stratford, 1996; Akaiyama-Jibiki et al., 1997; Boonaert et al., 1999).

The surface properties of microbial cells are involved in various industrially important phenomena, e.g., brewing yeast flocculation, acetic bacteria adhesion, and activated sludge formation. Flocculation of brewing yeast is probably the most extensively studied system concerning cell aggregates (Jin and Speers, 1998). There have been several models proposed to explain this phenomenon; however, the most widespread is based on calcium-dependent lectinmannan interactions (Miki et al., 1982). Later, the term "zymolectin," labeling any lectin-like molecules on the 
surface of Saccharomyces cerevisiae, was introduced (Speers et al., 1998), and these protein or glucoprotein structures with a specific carbohydrate binding domain enhancing cell flocculation were studied and isolated (Javadekar et al., 2000; Jin et al., 2001). Other authors, though, emphasize the role of the physicochemical properties (composition, charge, hydrophobicity) of the cell surface (Bowen and Cooke, 1989; Mestdagh et al., 1990; Smit et al., 1992; Dengis et al., 1995). Cell surface hydrophobicity has been considered by some authors as one of the major factors responsible for the flocculation of brewing yeast (Straver et al., 1993; Straver and Kijne, 1996) and flocculin, a hydrophobic proteinaceous cell surface factor, was identified (Smit et al., 1992). However, other studies contradicted the importance of hydrophobic interactions (Suzzi et al., 1994; van Hamersveld et al., 1994). Despite the extensive research that has been undertaken, the molecular basis and the exact mechanism of yeast flocculation is still not completely understood.

The brewing yeast used in this work under continuous culture conditions adhered to the surface of a carrier made of spent grains, a brewing byproduct (Brányik et al., 2001). This biocatalyst consisting of brewing yeast immobilized onto a cellulose-based carrier obtained from spent grains, containing mostly husks of the barley kernel, has been successfully applied in primary fermentation of lager beer (Brányik et al., 2002) and shows interesting features in terms of carrier costs. In order to enable its application in industrial-scale continuous beer fermentation, it is necessary to understand the immobilization process increasing its operational stability. Therefore, the goal of this study was to characterize the yeast's and the carrier's physicochemical surface properties and their changes in the course of the continuous culture. The hypothesis that the physicochemical interactions may lead to stable brewing yeast adhesion to spent grain particles was examined.

\section{MATERIALS AND METHODS}

\section{Microorganism and Medium}

The brewing yeast Saccharomyces uvarum (carlsbergensis), kindly supplied by a brewing company (UNICER, Bebidas de Portugal, S. Mamede de Infesta, Portugal), was cultivated for inoculation of the bubble-column reactor in $100 \mathrm{ml}$ of synthetic medium under aerobic conditions on a rotary shaker $(120 \mathrm{rpm})$ at $30^{\circ} \mathrm{C}$ for $30 \mathrm{hr}$. The synthetic medium contains (in $\mathrm{g}^{-1}$ ) $\mathrm{KH}_{2} \mathrm{PO}_{4}, 5.0$; $\left(\mathrm{NH}_{4}\right)_{2} \mathrm{SO}_{4}, 2.0$; $\mathrm{MgSO}_{4} .7 \mathrm{H}_{2} \mathrm{O}, 0.4$; yeast extract, 1.0 ; glucose 10.0; and its $\mathrm{pH}$ was adjusted to 5.0 using $\mathrm{H}_{2} \mathrm{SO}_{4}$.

\section{Carrier Preparation From Spent Grains and Continuous Culture Experiments}

The acid/base-treated carrier was prepared from dry spent grains $(100 \mathrm{~g})$ dispersed in $1,500 \mathrm{ml}$ of $3 \%(\mathrm{v} / \mathrm{v}) \mathrm{HCl}$ solution at $60^{\circ} \mathrm{C}$ for $2.5 \mathrm{hr}$ in order to hydrolyze the residual starchy endosperm and embryo of the barley kernel present in the spent grains. The mixture was then cooled, washed with water, and dried. The remaining solids $(\sim 30 \mathrm{~g})$, mainly the husks of the barley grain, were partially delignified by shaking $(120 \mathrm{rpm})$ in $500 \mathrm{ml}$ of $2 \%$ (w/v) $\mathrm{NaOH}$ solution at $30^{\circ} \mathrm{C}$ for $24 \mathrm{hr}$. After being washed several times with water until neutral $\mathrm{pH}$ and dried, the carrier $(\sim 10 \mathrm{~g})$ was ready to be used. The average surface area of carrier particles was $\mathrm{S}=0.59 \mathrm{~mm}^{2}$ as determined by image analysis (Vicente et al., 1996). The base-treated carrier was prepared from spent grains by the same procedure as described above without the acidic $(\mathrm{HCl})$ hydrolysis step.

All continuous experiments were carried out in a continuous bubble-column reactor (single tube) with a total working volume of $440 \mathrm{ml}$ (height-to-diameter ratio, 1.5). The inlet and outlet were situated 1 and $11.5 \mathrm{~cm}$ above the bottom of the reactor, respectively. The sedimentation barrier (semicircle plan, $1.5 \mathrm{~cm}$ radius) reached $1 \mathrm{~cm}$ above and $5 \mathrm{~cm}$ below the outlet. After placing the carrier $(6-7 \mathrm{~g}$ dry weight) in the reactor, $100 \mathrm{ml}$ of precultured brewing yeast suspension were added, after which the reactor was filled with synthetic medium. The continuous feed was started after $16 \mathrm{hr}$ of batch growth always at a dilution rate of $0.195 \mathrm{hr}^{-1}$. In the first continuous experiment, the dilution rate $\left(\mathrm{D}_{1}\right)$ was kept constant at $0.195 \mathrm{hr}^{-1}$. During the second type of continuous experiment, the dilution rate profile $\left(\mathrm{D}_{2}\right)$ started at $0.195 \mathrm{hr}^{-1}$ and was increased after $30 \mathrm{hr}$ to $0.375 \mathrm{hr}^{-1}$, which was then maintained constant. In the course of the third type of continuous culture, the dilution rate profile $\left(\mathrm{D}_{3}\right)$ was increased two times, first after $30 \mathrm{hr}$ from 0.195 to $0.375 \mathrm{hr}^{-1}$ and subsequently at $55 \mathrm{hr}$ from 0.375 to $0.66 \mathrm{hr}^{-1}$, which was then kept constant. The medium was supplied at the bottom of the reactor by means of a peristaltic pump (Watson Marlow 101 U/R, Falmouth, England). Sterile air was passed into the bubble column at $0.91 \mathrm{~min}^{-1}$ through a pipe with four holes (1 $\mathrm{mm}$ diameter each). Under these conditions, the carrier in the reactor was in continuous motion and did not tend to settle.

\section{Immobilized Biomass Determination}

A sample containing approximately $0.4 \mathrm{~g}$ of dry biocatalyst (carrier + immobilized cells) was taken from the reactor. The bulk liquid was removed with a syringe and the carrier was washed with $2 \times 100 \mathrm{ml}$ of distilled water in order to remove the free cells captured between the carrier particles. Then the biocatalyst was allowed to sediment and the bulk liquid with the free cells and the loosely bound cells liberated from the carrier were removed with a syringe. The free biomass and the loosely bound cells were not considered to be a part of the immobilized biomass. The biocatalyst was then filtered and washed with $400 \mathrm{ml}$ of distilled water on a paper filter in order to remove the components of the medium from the sample. 
Then the biocatalyst together with the biomass liberated from the carrier during the washing was removed from the filter, homogenized, and dried at $105^{\circ} \mathrm{C}$ for $12 \mathrm{hr}$. An amount of approximately $0.2 \mathrm{~g}$ dry biocatalyst was weighed into an Erlenmeyer flask with $50 \mathrm{ml}$ of 3\% (w/v) $\mathrm{NaOH}$ solution and was shaken at $120 \mathrm{rpm}$ for $24 \mathrm{hr}$. During this time, the immobilized cells were completely removed from the carrier, as was verified under the microscope. The cell-free carrier was filtered and after being carefully washed on the filter with $400 \mathrm{ml}$ of distilled water was dried at $105^{\circ} \mathrm{C}$ for $5 \mathrm{hr}$. The amount of immobilized yeast biomass was determined from the weight difference before and after the treatment with caustic. Corrections of the biomass weight for the losses of carrier itself were carried out by blank experiments with clean carrier.

\section{Sedimentation Test}

The outflow from the bubble-column rector was collected, centrifuged, and washed twice with $250 \mathrm{mM} \mathrm{NaCl}$ solution, the $\mathrm{pH}$ of which has been adjusted to 3.0 by adding $150 \mu \mathrm{l}^{-1}$ concentrated $\mathrm{HCl}$. A $24 \mathrm{ml}$ volume of cell suspension in $250 \mathrm{mM} \mathrm{NaCl}$ solution $\left(\sim 0.7 \mathrm{~g} \mathrm{l}^{-1}\right.$ dry cell weight) was placed into a $25 \mathrm{ml}$ graduated cylinder. In order to verify whether the cell aggregate formation was promoted by $\mathrm{Ca}^{2+}$ ions, $1 \mathrm{ml}$ of $100 \mathrm{mM} \mathrm{CaCl}_{2}$ was added and the cell suspension was thoroughly mixed by inversion of the cylinder and the cells were then allowed to settle. In the course of the sedimentation, samples of $200 \mu \mathrm{l}$ were taken at the $20 \mathrm{ml}$ level and their absorbance at $620 \mathrm{~nm}$ was immediately measured to obtain a sedimentation profile (Domingues et al., 1999). The sedimentation properties of the nonimmobilized yeast were expressed as the absorbance of cell suspension after $30 \mathrm{~min}$ of sedimentation $\left(\mathrm{A}_{30}\right)$ related to the initial absorbance $\left(\mathrm{A}_{0}\right)$ : settled fraction $(\%)=$ $100 \times\left[1-\left(\mathrm{A}_{30} / \mathrm{A}_{0}\right)\right]$.

\section{Microbial Adhesion to Hydrocarbons (MATH Tests)}

Cell surface hydrophobicity of outflow cells was determined by the ability of yeast to adhere to xylenes (Rosenberg and Doyle, 1990). A suspension of nonimmobilized yeast cells collected from the outflow of the reactor $(1 \mathrm{ml}$, $\sim 1.2 \mathrm{~g} \mathrm{l}^{-1}$ dry cell weight) in $250 \mathrm{mM} \mathrm{NaCl}$ solution was vortexed for $60 \mathrm{sec}$ with $250 \mu \mathrm{l}$ of xylenes and mixed (Sigma Chemical, Steinheim, Germany). The high electrolyte concentration and acidic $\mathrm{pH}$ were used to avoid charge interference between cells and solvent droplets (Busscher et al., 1995; Briandet et al., 1999). Then the phases were allowed to separate for $15 \mathrm{~min}$ before a sample of $200 \mu \mathrm{l}$ was carefully taken from the aqueous phase and the absorbance at $620 \mathrm{~nm}$ was measured (A). Cells in control tubes without xylenes were quantified to determine the initial absorbance of the suspension $\left(\mathrm{A}_{0}\right)$. Yeast hydrophobicity was calculated by using the following equation: adhesion to xylenes $(\%)=100 \times\left[1-\left(\mathrm{A} / \mathrm{A}_{0}\right)\right]$. Every assay was performed in triplicate.

\section{Contact Angle Measurement}

Either nonimmobilized cells from the reactor outflow or immobilized cells $(\sim 0.5 \mathrm{~g}$ biocatalyst in dry state $)$ removed from the carrier by vigorous mixing $(600 \mathrm{rpm}, 2 \mathrm{~cm}$ magnetic bar, $100 \mathrm{ml} 250 \mathrm{mM} \mathrm{NaCl}$ ) were harvested daily by centrifugation $(3,000 \mathrm{~g}, 10 \mathrm{~min})$ during the continuous experiment and then washed with increasing concentrations of ethanol $(10 \%, 20 \%$, and $50 \%)$. The optical density of the final cell suspension in 50\% ethanol was adjusted to $1.2 \mathrm{~g} \mathrm{l}^{-1}$ dry cell weight. This suspension was immersed into a sonication bath for $2 \mathrm{~min}$ in order to break cell clusters. A solution of $20 \mathrm{~g} \mathrm{l}^{-1}$ of agar and $10 \%$ of glycerol was cast onto a microscope slide $(75 \times 25 \mathrm{~mm})$. An aliquot of $1 \mathrm{ml}$ of the yeast suspension was spread uniformly over the solidified agar layer and was let dry at $25^{\circ} \mathrm{C}$ for approximately $60 \mathrm{~min}$. Subsequently, four more layers were added, each followed by a drying period of $60 \mathrm{~min}$, then the cell layers were used for contact angle measurement (Henriques et al., 2002). Previous to contact angle measurements, base-treated carrier particles were fixed on a microscopic slide by an adhesive tape. Contact angles were measured by the sessile drop technique (drop volume of $\sim 3 \mu \mathrm{l}$ ) on the cell lawns and carrier particles using a contact angle apparatus (Kruss, Hamburg, Germany). The measurements were performed at $25^{\circ} \mathrm{C}$ using three different liquids: water, formamide, and $\alpha$-bromonaphthalene. At least 20 readings of contact angles per sample were carried out for each liquid. The total surface tension $\left(\gamma^{\text {tot }}\right)$ and its components $\left(\gamma^{\mathrm{LW}}, \gamma^{+}, \gamma^{-}, \gamma^{\mathrm{AB}}\right)$, the values of the free energy of interaction between cells and water $\left(\Delta G_{c w c}^{t o t}\right)$ and its components $\left(\Delta G_{c w c}^{L W}, \Delta G_{c w c}^{A B}\right)$ and the free energy of interaction between cells and carrier in water $\left(\Delta G_{c w s}^{t o t}\right)$ and its components $\left(\Delta G_{c w s}^{A B}, \Delta G_{c w s}^{L W}\right)$ were calculated according to van Oss et al. (1988).

\section{Nile Red Fluorescence in the Presence of Spent Grain Particles}

Acid/base- and base-treated carrier (0.02 g in dry state) was mixed with $0.3 \mathrm{ml}$ of $2 \mathrm{mM}$ Nile red (Fluka, Buchs, Switzerland) solution in methanol for UV spectroscopy (Sigma Chemical) and was let dry for $4 \mathrm{hr}$ at $30^{\circ} \mathrm{C}$. Twodimensional fluorescence spectra in the range of excitation wavelengths of 500-620 nm and emission wavelengths of $550-650 \mathrm{~nm}$ were determined with a Hitachi F-4500 fluorescence spectrophotometer (Hitachi, Tokyo, Japan).

\section{Zeta Potential Measurement}

The electrophoretic mobility of the yeast from the reactor outflow was determined with a Zeta-Meter System 3.0 (Zeta-Meter). Cells were harvested by centrifugation and then resuspended in $10 \mathrm{mM} \mathrm{KNO}_{3}$ to a concentration of 
$0.85 \mathrm{~g} \mathrm{l}^{-1}$ dry cell weight. The $\mathrm{pH}$ was adjusted with $\mathrm{HNO}_{3}$ (Dengis et al., 1995). The acid/base-treated carrier $(0.5 \mathrm{~g}$ in dry state) was triturated in a mortar and then suspended in $100 \mathrm{ml}$ of $10 \mathrm{mM} \mathrm{KNO}$. The suspension of carrier particles was filtered through a polyester mesh (Estal mono PE 18, Seidengazefabrik AG Thal, Switzerland) with mesh openings of $18 \times 18 \mu \mathrm{m}$ and the $\mathrm{pH}$ was adjusted with $\mathrm{HNO}_{3}$. Either the cell suspension or the carrier particles suspension was filled into the electrophoresis cell and after at least 40 electrophoretic mobility readings the average zeta potential was calculated.

\section{Holocellulose Determination}

The carrier made of spent grains $(\sim 5 \mathrm{~g})$ was soaked in water $(160 \mathrm{ml})$. Acetic acid (10 drops) and $1.5 \mathrm{~g}$ sodium chlorite (Acros Organics, Geel, Belgium) were added and the mixture was kept at $80-90^{\circ} \mathrm{C}$ for $1 \mathrm{hr}$. The addition of acetic acid and sodium chlorite and heating was repeated three times. The isolated white holocellulose (a combina-
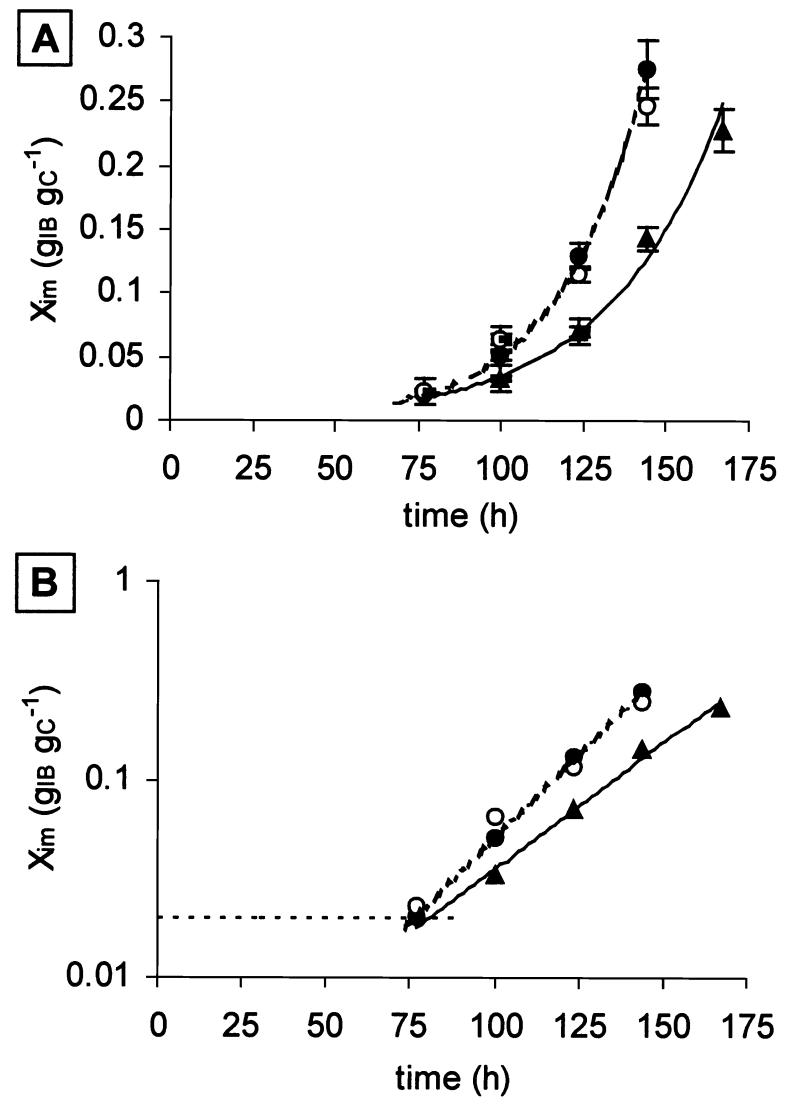

Figure 1. A: The development of the immobilized biomass, $X_{i m}\left(\mathrm{~g}_{\mathrm{IB}}\right.$ $\mathrm{g}_{\mathrm{C}}^{-1}$ ), on the surface of the acid/base-treated carrier during continuous experiments at different dilution rate profiles: $X_{i m}^{1}$ (closed triangle) at $\mathrm{D}_{1}$, constant dilution rate $\left(0.195 \mathrm{hr}^{-1}\right) ; X_{i m}^{2}$ (open circle) at $\mathrm{D}_{2}$, one-step increase (at $30 \mathrm{hr}$ the D increased from 0.195 to $0.375 \mathrm{hr}^{-1}$ ); $X_{i m}^{3}$ (closed circle) at $\mathrm{D}_{3}$, two-step increase (at $30 \mathrm{hr}$ the $\mathrm{D}$ increased from 0.195 to $0.375 \mathrm{hr}^{-1}$ and at $55 \mathrm{hr}$ from 0.375 to $0.66 \mathrm{hr}^{-1}$ ). B: Logarithmically plotted $X_{i m}^{1,2,3}$ at $\mathrm{D}_{1,2,3}$. $\mathrm{T}_{\mathrm{exp} ; 1,2,3}$, start of the exponential yeast accumulation phase. tion of cellulose and hemicellulose) was filtered, washed with water and acetone, and weighed after drying at $105^{\circ} \mathrm{C}$.

\section{Scanning Electron Microscopy}

A sample of the biocatalyst $(\sim 0.2 \mathrm{~g}$ in dry state) was washed with $50 \mathrm{ml}$ of distilled water and then with $20 \mathrm{ml}$ of ethanol with increasing concentration $(10 \%, 25 \%, 50 \%$, $75 \%, 90 \%$, and $100 \%$ ). Finally, the sample was dried for several days in an exsiccator. The carrier with immobilized yeast was coated with a thin gold layer by vacuum evaporation and subsequently the observations by scanning electron microscopy (SEM) were performed.

\section{RESULTS}

Several continuous experiments in a bubble-column reactor have been carried out at different dilution rate (D) profiles in order to study the rate of the yeast immobilization onto different carrier particles, the stability of the yeast biofilm, and the changes in the yeast surface properties during the continuous experiment.

\section{Yeast Immobilization Onto Spent Grains}

The immobilization of the brewing yeast onto carrier particles prepared from spent grains, both by acid/base and base treatment, was characterized by an initial slow yeast accumulation rate (lag phase) followed by an exponential phase of biomass accumulation (Fig. 1). The time corresponding to the beginning of the exponential phase of the immobilized biomass accumulation $\left(\mathrm{T}_{\exp }\right)$ was obtained by plotting on a semilog scale the variation of immobilized biomass vs. time and determining the time corresponding to the intersection of this line with an immobilized biomass load of $X_{\text {im }}=0.02 \mathrm{~g}_{\mathrm{IB}} \mathrm{g}_{\mathrm{C}}^{-1}$ (where IB is the dry immobilized biomass weight and $C$ the dry carrier weight), as it was experimentally observed that the exponential biomass accumulation onto the support occurred only at biomass loads higher than that value (Fig. 1).

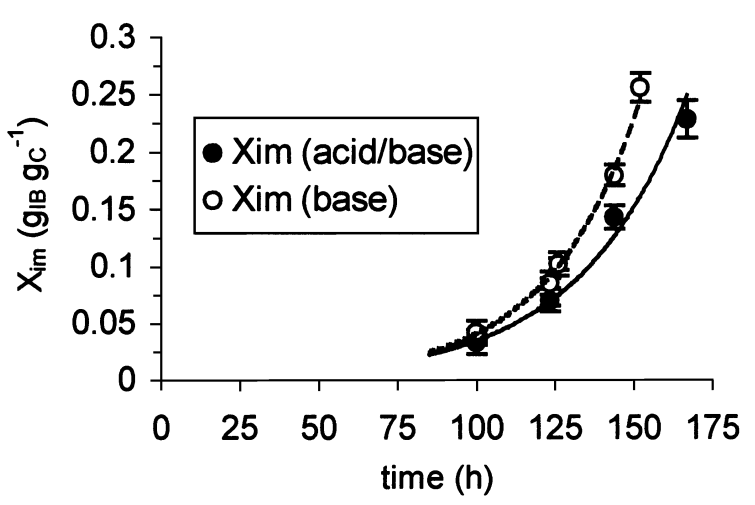

Figure 2. The development of the immobilized biomass, $X_{i m}\left(\mathrm{~g}_{\mathrm{IB}} \mathrm{g}_{\mathrm{C}}^{-1}\right)$ on the surface of two carriers prepared by acid/base and base treatment of the spent grains at dilution rate $\mathrm{D}_{1}=0.195 \mathrm{hr}^{-1}$. 

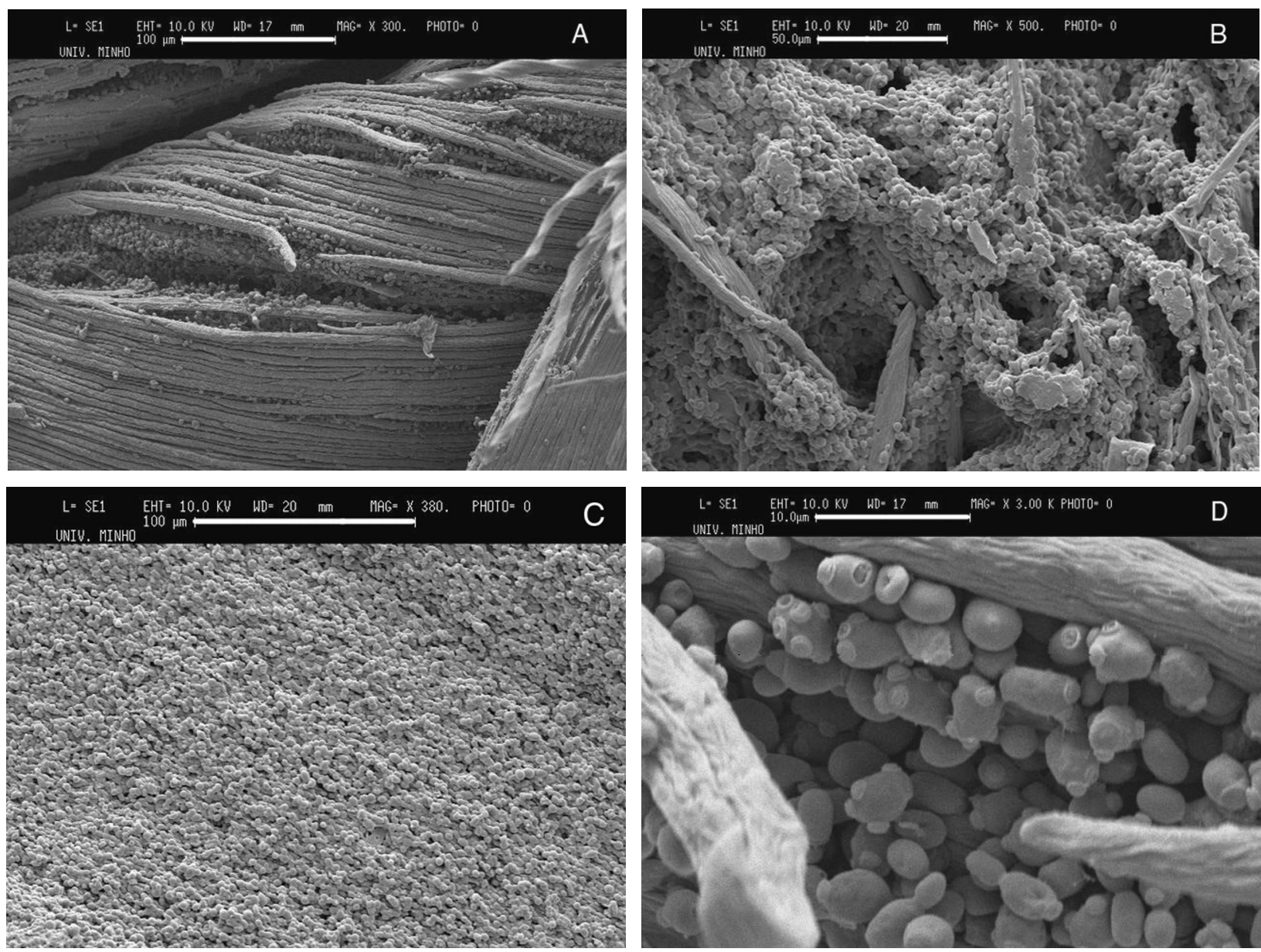

Figure 3. Photomicrographs (SEM) of carrier particles with yeast cells. A: White bar, $100 \mu \mathrm{m}\left(X_{i m}=0.06 \mathrm{~g}_{\mathrm{IB}} \mathrm{g}_{\mathrm{C}}^{-1}\right)$. B: White bar, $50 \mu \mathrm{m}\left(X_{i m}=\right.$ $\left.0.42 \mathrm{~g}_{\mathrm{IB}} \mathrm{g}_{\mathrm{C}}^{-1}\right)$. C: White bar, $100 \mu \mathrm{m}\left(X_{i m}=0.42 \mathrm{~g}_{\mathrm{IB}} \mathrm{g}_{\mathrm{C}}^{-1}\right)$. D: White bar, $10 \mu \mathrm{m}\left(X_{i m}=0.06 \mathrm{~g}_{\mathrm{IB}} \mathrm{g}_{\mathrm{C}}^{-1}\right)$.

The exponential phase of the yeast biomass accumulation can be described by

$$
\frac{d X_{i m}}{d t}=m X_{i m}
$$

where $\mathrm{m}$ is overall yeast accumulation rate coefficient $\left(\mathrm{hr}^{-1}\right)$. Continuous experiments with acid/base-treated spent

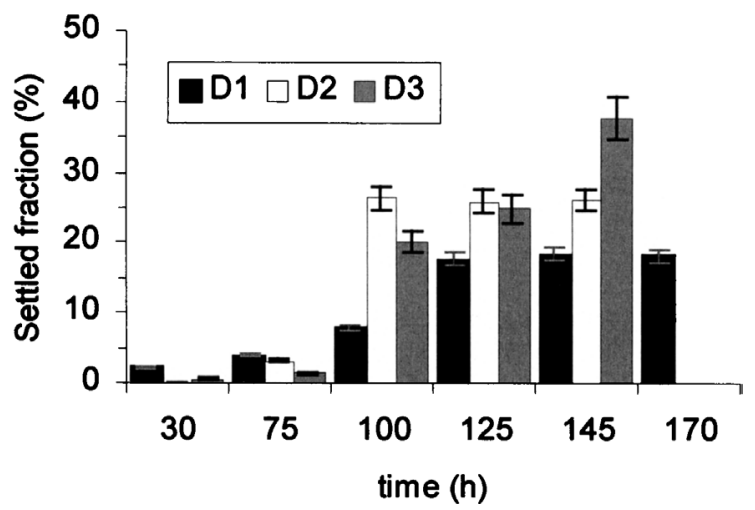

Figure 4. Settled fraction of the yeast at different time after the start of the continuous reactor operation. Cells obtained from reactor outflow at different dilution rate profiles $\left(D_{1}, D_{2}, D_{3}\right)$. grains at three different dilution rate profiles $\left(\mathrm{D}_{1}, \mathrm{D}_{2}, \mathrm{D}_{3}\right)$ were carried out (Fig. 1). The dilution rate profile $\mathrm{D}_{2}$ speeded up the onset of the exponential biomass accumulation rate compared to $D_{1}$ profile, as can be seen from the smaller value of $\mathrm{T}_{\exp ; 2}$. An increase in the rate of yeast accumulation from $\mathrm{m}_{1}=0.029 \pm 0.005$ to $\mathrm{m}_{2}=0.039 \pm 0.007 \mathrm{hr}^{-1}$ was also observed. The dilution rate profile $\mathrm{D}_{3}$ did not result in increased $\mathrm{T}_{\text {exp;3 }}$ and $\mathrm{m}_{3}$ in comparison with $\mathrm{D}_{2}$.

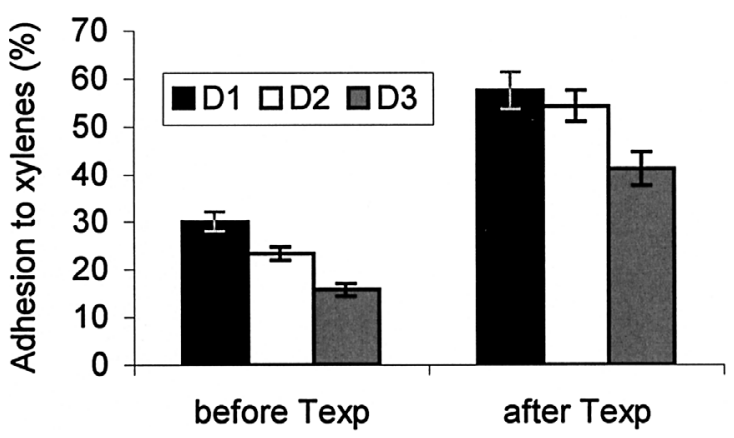

Figure 5. Adhesion of yeast from reactor outflow to hydrophobic xylenes (MATH test) before and after the beginning of the exponential accumulation phase of the immobilized biomass $\left(\mathrm{T}_{\text {exp }}\right)$ at different maximum dilution rate profiles $\left(\mathrm{D}_{1}, \mathrm{D}_{2}, \mathrm{D}_{3}\right)$. 
Table I. Average contact angles and respective standard deviations obtained with three test liquids over a lawn of brewing yeast (nonimmobilized or immobilized) and on the surface of base-treated carrier particles.*

\begin{tabular}{lrcr}
\hline \multirow{3}{*}{ Yeast/carrier } & \multicolumn{3}{c}{ Contact angle $\left(^{\circ}\right)$} \\
\cline { 2 - 4 } \multicolumn{1}{c}{ Water } & Formamide & $\alpha$-bromonaphthalene \\
\hline NIC before $\mathrm{T}_{\exp }$ & $7.2 \pm 1.6$ & $8.8 \pm 1.5$ & $32.4 \pm 2.4$ \\
NIC after $\mathrm{T}_{\exp }$ & $9.5 \pm 1.5$ & $9.5 \pm 1.4$ & $24.7 \pm 2.3$ \\
Immobilized cells & $10.4 \pm 1.6$ & $10.5 \pm 0.8$ & $23.2 \pm 1.0$ \\
Base-treated carrier & $80 \pm 10$ & $58 \pm 4$ & $23 \pm 3$ \\
\hline
\end{tabular}

*NIC, nonimmobilized cells; $\mathrm{T}_{\mathrm{exp}}$, start of the exponential biomass accumulation phase.

The yeast biomass accumulation on the surface of carrier particles prepared by acid/base and base-only treatment of the spent grains was compared at the dilution rate $D_{1}=$ $0.195 \mathrm{hr}^{-1}$. In the case of the less wettable base-treated carrier, the onset of the exponential yeast accumulation phase $\left(\mathrm{T}_{\text {exp }}\right)$ and the overall yeast accumulation coefficient $\left(\mathrm{m}_{1 \text {; base }}=0.035 \pm 0.005 \mathrm{hr}^{-1}\right)$ was approximately $4 \mathrm{hr}$ shorter and $\sim 17 \%$ higher, respectively (Fig. 2).

Microscopic observations (SEM) of the biocatalyst at different stages of the colonization revealed a gradual yeast biofilm formation. Initially, local biomass accumulations were observed on the surface of the carrier while other large zones were not colonized by yeast cells (Fig. 3A). Further accumulation of the immobilized biomass led to formation of a yeast biofilm of different thickness (Fig. 3B and C). A detailed observation of the brewing yeast on the surface of the carrier show cells of different age, ranging from budding cells to mother cells with several scars (Fig. 3D).

\section{Surface Characteristics of Brewing Yeast Cells}

Microscopic observations of the reactor outflow showed an increasing number of cell clusters appearing after the onset of the exponential cell immobilization phase $\left(\mathrm{T}_{\text {exp }}\right)$ while sedimentation tests revealed an increase in the sedimentation of the nonimmobilized yeast at the same time (Fig. 4). For example, in the experiments at the dilution rate profile
$\mathrm{D}_{2}$ and $\mathrm{D}_{3}$, there was a sudden increase of the sedimentation of nonimmobilized yeast between 75 and $100 \mathrm{hr}$ of reactor operation (Fig. 4). Approximately at the same time $\left(T_{\text {exp }}\right)$, biomass immobilization entered into the exponential phase. In the case of $D_{1}$, the increase in sedimentation as well as $\mathrm{T}_{\exp }$ was slightly postponed (Figs. 1 and 4 ). The addition of $\mathrm{CaCl}_{2}$ had no effect on the sedimentation rate of the cell suspensions.

MATH tests based on partitioning of cells between water and xylene phase have been carried out in order to evaluate the changes of the relative surface hydrophobicity of the nonimmobilized cells during the continuous experiments. The average values of at least 5 MATH tests carried out before and after $\mathrm{T}_{\exp }$ at different dilution rates showed an almost uniform 30\% increase of nonimmobilized cell's surface hydrophobicity (Fig. 5). Observations under the optical microscope $(\times 150$ magnification) revealed an accumulation of the yeast cells on the surface of the $x y-$ lene droplets.

The contact angles of water and $\alpha$-bromonaphthalene were very similar to those obtained for wine yeast (Vernhet and Bellon-Fontaine, 1995) and rank the brewing yeast strain among strongly hydrophilic. The contact angles of $\alpha$-bromonaphthalene decreased in the order nonimmobilized cells before $T_{\exp }>$ nonimmobilized cells after $T_{\exp }>$ immobilized cells (Table I).

The total surface tension $\left(\gamma^{\text {tot }}\right)$ of the brewing yeast surface and its components calculated from contact angles clearly place the brewing yeast among cells with hydrophilic surfaces. These are characterized with $\gamma^{\mathrm{LW}} \simeq 40 \mathrm{~mJ}$ $\mathrm{m}^{-2}, \gamma^{+} \simeq 0 \mathrm{~mJ} \mathrm{~m}^{-2}$, and $\gamma^{-}>28 \mathrm{~mJ} \mathrm{~m}^{-2}$ (van Oss, 1995), which is in accordance with surface tension components of the brewing yeast under the conditions of continuous culture (Table II). Among surface tension components, $\gamma^{\mathrm{LW}}$ (Lifshitz-van der Waals interaction) and $\gamma^{-}$(the electrondonor parameter of the surface tension component) are the most important for cell surface interactions.

The higher value obtained for $\gamma^{-}$as compared to $\gamma^{+}$is not surprising since the zeta potential measurements also showed a negative surface charge of the yeast cells (Fig. 6). At $\mathrm{pH}$ values from 3.0 to 5.0 and ionic strength of $10 \mathrm{mM}$, the zeta potential covers a range of -11 to $-15 \mathrm{mV}$. This

Table II. Surface tension and free energy of interaction between brewing yeast (immobilized or nonimmobilized) immersed in water (cwc), between base-treated carrier particles in water (sws), and between cell and base-treated carrier in water (cws).*

\begin{tabular}{|c|c|c|c|c|c|c|}
\hline \multirow[b]{2}{*}{ Yeast/carrier (interacting system) } & \multicolumn{6}{|c|}{ Surface tension ${ }^{\mathrm{a}}$ and free energy of interaction ${ }^{\mathrm{b}}\left(\mathrm{mJ} \mathrm{m}^{-2}\right)$} \\
\hline & $\gamma^{\mathrm{LW}}$ & $\gamma^{\mathrm{AB}}$ & $\gamma^{\mathrm{tot}}$ & $\Delta G^{L W}$ & $\Delta G^{A B}$ & $\Delta G^{t o t}$ \\
\hline NIC before $T_{\exp }(\mathrm{cwc})$ & 37.7 & 19.0 & 56.7 & -4.4 & 35.5 & 31.1 \\
\hline NIC after $T_{\exp }(\mathrm{cwc})$ & 40.3 & 15.9 & 56.1 & -5.7 & 37.1 & 31.4 \\
\hline $\mathrm{IC}(\mathrm{cwc})$ & 40.9 & 15.0 & 55.9 & -6.0 & 37.5 & 31.5 \\
\hline BTC (sws) & 40.9 & 0.6 & 41.5 & -6.0 & -51.6 & -57.6 \\
\hline IC and BTC in water (cws) & & & & -6.0 & 1.8 & -4.2 \\
\hline
\end{tabular}

\footnotetext{
*NIC, nonimmobilized cells; $\mathrm{T}_{\text {exp }}$, start of the exponential biomass accumulation phase; IC, immobilized cells; BTC, base-treated carrier.

${ }^{\mathrm{a}}$ Apolar $\left(\gamma^{\mathrm{LW}}\right)$ and polar $\left(\gamma^{\mathrm{AB}}\right)$ components of the total surface tension $\left(\gamma^{\mathrm{tot}}\right)$.

${ }^{\mathrm{b}}$ Apolar $\left(\Delta G^{L W}\right)$ and polar $\left(\Delta G^{A B}\right)$ component of the total free energy of interaction $\left(\Delta G^{\text {tot }}\right)$.
} 


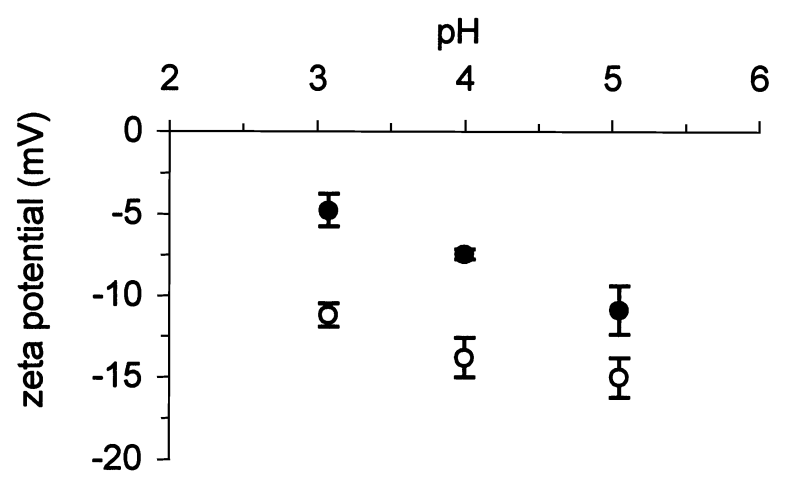

Figure 6. Values of zeta potential as a function of $\mathrm{pH}$ for brewing yeast (open circle) and acid/base-treated carrier particles (closed circle) in $10 \mathrm{mM} \mathrm{KNO}_{3}$.

electron-donor nature of the yeast cell surface may arise from the negatively charged phosphate and carboxyl groups (Rose, 1984).

\section{Surface Characteristics of Spent Grain Particles}

The contact angle measurements on the surface of solid particles required a sufficiently large and flat area that would not absorb the drop of the test liquid. While the measurements on acid/base-treated carrier failed due to the highly wettable character of the carrier, in the case of the base-treated spent grains, there was a portion of sufficiently large and hydrophobic carrier particles allowing the placing of the test drop. The average contact angles and the calculated surface tensions and Gibbs free energies of interaction of the base-treated spent grain particles are presented in Tables I and II.

The zeta potential of the acid/base-treated spent grain particles was measured after filtering the triturated carrier powder, suspended in $10 \mathrm{mM} \mathrm{KNO}$, through a polyester mesh with mesh size of $18 \times 18 \mu \mathrm{m}$. The carrier particles, smaller than $30 \mu \mathrm{m}$ in diameter, had a negative zeta potential in the studied $\mathrm{pH}$ range (3.0-5.0). The zeta potential of the acid/base-treated carrier particles was lower than that of the brewing yeast under the same conditions (Fig. 6).

Nile red is a hydrophobic dye, the fluorescent properties of which highly depend on the polarity of the probe environment (Krishna, 1999). It acts as a hydrophobic probe in which the fluorescence maxima exhibit a spectral blue shift to shorter wavelengths, proportional to the hydrophobicity of the environment (Greenspan and Fowler, 1985). The spectral shift of excitation/emission maximum (EX/EM) of Nile red in contact with acid/base- and basetreated spent grains was $603 / 645$ and $591 / 640 \mathrm{~nm}$, respectively, indicating the more hydrophobic (less wettable) character of the base-treated spent grains carrier. The maximum excitation and emission band width of the twodimensional fluorescence peak of Nile red deposited on the surface of carrier particles was approximately 80 and $60 \mathrm{~nm}$, respectively.

\section{DISCUSSION}

Although some of the experiments (MATH and sedimentation tests) were performed only with nonimmobilized cells, it can be assumed that the changes in surface properties and morphology of the nonimmobilized yeast during the continuous culture experiments reflect, to a certain extent, the properties of the whole microbial population in the system (both immobilized and nonimmobilized cells). In fact, the knowledge of the difference between the surface properties of the nonimmobilized cells at the beginning of the continuous culture (characterized by a low immobilized biomass load, $X_{i m}$ ) and at a later stage (displaying higher values of $X_{i m}$ ) can help explain the mechanism of both cellcell attachment and cell-carrier adhesion. This hypothesis is based on the dynamic character of the continuous culture with the immobilized cell system under study, where opposite processes such as cell adhesion/release, adsorption/ desorption, and attachment/detachment take place (Peyton and Characklis, 1995).

The surface properties and morphology of the brewing yeast population in continuous culture cannot be considered constant in time. The increasing number of cell aggregates throughout the continuous culture, as observed by sedimentation tests (Fig. 4), can be explained both by the selective pressure in the continuous reactor and by the occasional detachment of the yeast biofilm from the carrier particles. The selective pressure was created by the sedimentation barrier of the reactor's outflow, retaining rather the large cell clusters than the single cells, and by the cell-carrier interaction favoring the retention of the cells with surface properties advantageous for immobilization.

\section{Cell-Carrier Adhesion}

Immobilized brewing yeast were found on flat and open zones of carrier particles (Fig. 3C) where they could not receive protection against fluid flow as in the shelters (Fig. 3A and B). This implies the existence of the adhesion of free cells to carrier particles driven by interfacial interactions. Generally, the phenomenon of microbial adhesion to solid surfaces results from an interplay between electrostatic and nonelectrostatic interactions (Mozes et al., 1987).

The Derjaguin-Landau-Verwey-Overbeek (DLVO) theory allows the computation of the interaction potential energy between a spherical particle (cell) and a flat plate (spent grains) approaching each other by taking into consideration the dispersion and the electrostatic interactions (van Loosdrecht et al., 1989; Bhattacharjee and Elimelech, 1997). This approach was applied here, using a cell radius of $3 \mu \mathrm{m}$, dielectric constant of 78.5 (pure water), an estimated Hamaker constant of $0.8 \mathrm{kT}$ for biological particles in water (Nir, 1977; van Hamersveld et al., 1994), ionic strength of $10 \mathrm{mM}$, and zeta potentials of cells $(-12 \mathrm{mV})$ and spent grain particles $(-5 \mathrm{mV})$ at the $\mathrm{pH}$ of the continuous fermentation $(\sim 3.4)$. The small potential energy barrier between a brewing yeast cell and a spent grain 
particle $(9 \mathrm{kT})$ at $3 \mathrm{~nm}$ indicates the possibility of the capture of the cell in close contact with the carrier (Fig. 7). At ionic strengths higher than $10 \mathrm{mM}$, e.g., real microbial culture media (Boonaert et al., 1999), there would be no potential energy barrier between cells and carrier at all (data not shown).

However, the DLVO theory counts only with long-range forces and does not allow predictions of interaction energy to be made at short distances. Therefore, an approach based on a balance of cell-liquid, carrier-liquid, and cell-carrier interfacial free energies was used to estimate whether the physicochemical surface properties of cells and carrier would lead to adhesion. It was found that the carrier contains hydrophobic particles, namely, among the basetreated carrier, showing very negative values of the free energy of interaction between two carrier surfaces (s) in water (w): $\Delta G_{\text {sws }}^{\text {tot }}=-57.6 \mathrm{~mJ} \mathrm{~m}^{-2}$ (Table II). It can be assumed that the outmost waxy layer of the barley husks and/or lignin, a common part of natural cellulosic materials, might serve as a hydrophobic interaction site for yeast adhesion. In consequence of this, the total free energy of interaction $\left(\Delta G_{c w s}^{t o t}\right)$ between the brewing yeast (c) and the base-treated carrier particles (s) in the presence of water (w) is negative $\left(\Delta G_{c w s}^{t o t}=-4.2 \mathrm{~mJ} \mathrm{~m}^{-2}\right)$, and thus the adhesion is likely to occur. Since the overall free energy of the polar acid-base interactions in the cell-water-carrier (cws) system is close to zero $\left(\Delta G_{c w s}^{A B}=1.8 \mathrm{~mJ} \mathrm{~m}^{-2}\right)$, the apolar van der Waals interactions $\left(\Delta G_{c w s}^{L W}=-6.0 \mathrm{~mJ} \mathrm{~m}^{-2}\right)$ will strengthen the cell-carrier adhesion (Table II). These results are in accordance with the adhesion of wine yeast to apolar surfaces (polycarbonate, polystyrene) with surface tensions very similar to those of the hydrophobic zones on spent grain particles (Vernhet and Bellon-Fontaine, 1995). Bakers' yeast attachment to plastics and mat formation, requiring a fungal cell surface glycoprotein encoded by FLO11 gene, is also indicating the role of hydrophobic

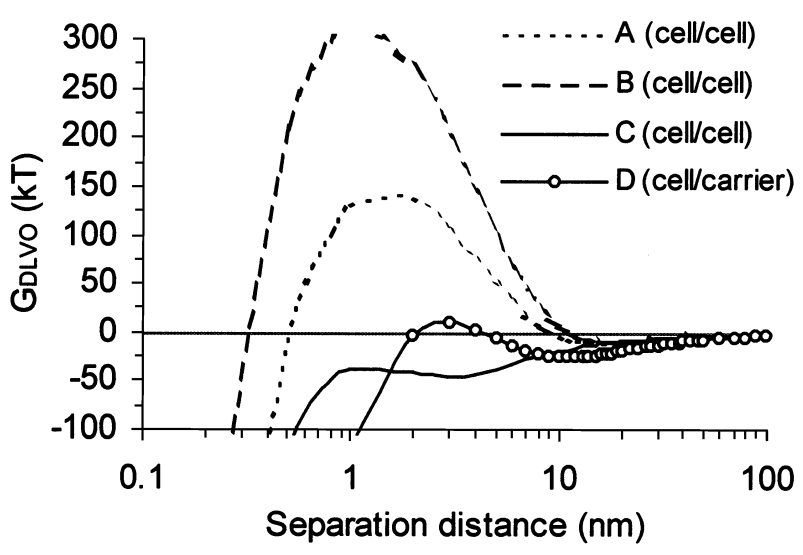

Figure 7. Variation of the interaction free energy $\left(\mathrm{G}_{\mathrm{DLVO}}\right)$ as a function of the separation distance between two cells (cell/cell) and between a cell and a flat surface of the spent grains (cell/carrier), calculated according to DLVO theory: cell radius $3 \mu \mathrm{m}$; Hamaker constant $0.8 \mathrm{kT}$. A, cell zeta potential $-12 \mathrm{mV} /$ ionic strength $10 \mathrm{mM} ; \mathrm{B},-15 \mathrm{mV} / 10 \mathrm{mM}$;,$-12 \mathrm{mV} /$ $100 \mathrm{mM}$; D, cell, carrier zeta potential $-12,-5 \mathrm{mV} / 10 \mathrm{mM}$. interactions. The Saccharomyces cerevisiae FLO11 bakers' yeast strain was found more hydrophobic than the strain poorly adhering to polystyrene and lacking the FLO11 gene (Reynolds and Fink, 2001).

Considering the prevailing apolar character of the cellcarrier interaction, the yeast adhesion rate to the more hydrophobic base-treated carrier should be higher than to the acid/base-treated carrier. Indeed, the adhesion rate of yeast to the less wettable base-treated carrier was higher (Fig. 2), but on the other hand, the hydrophobic character of the base-treated carrier resulted in its floating and subsequent partial washout from the reactor. Therefore, the surface properties of the carrier made of spent grains have to be optimized in terms of biomass load and solid-phase dispersion in water phase. In other words, the equilibrium between the carrier's hydrophobic (cell adhesion sites) and hydrophilic (wettable) properties should be maintained by shortening the acidic hydrolysis of the spent grains. The resulting simplified preparation procedure, consisting only of the base treatment, will have also an attractive economic feature.

Although the surface tension values of the base-treated carrier (Table II) cannot be regarded as an average value for the overall carrier surface, they proved the presence of very hydrophobic areas and moieties on the surface of the spent grains. In view of the natural character of the carrier, having nonhomogeneous surface properties and chemical composition (containing 90\% w/w of holocellulose), a similarly nonhomogeneous immobilized biomass distribution can be expected, especially at the beginning of the exponential biomass accumulation phase $\left(\mathrm{T}_{\exp }\right)$.

\section{Cell-Carrier Adsorption}

Apart from the physicochemical interactions between yeast cell and carrier particle surfaces, the spatial retention of yeasts in various shelters (crevices, pores, tangled threads) on the carrier surface can result in local biomass accumulations (Fig. 3A and B). The roughness elements of the carrier provide shelter for cells from the shear forces exerted by fluid flow and also increase the total surface area available for colonization. A necessary condition for such immobilization is a sufficient pore size (diameter) allowing the intrusion of the microbe (Messing and Oppermann, 1979). As it can be seen from the size of the crevices and from the degree of colonization, the brewing yeast could easily reach the inside of a sufficiently large crevice where they multiplied and filled the sheltered zone (Fig. 3A). The forced contact of growing cells inside the pores could also lead to cell aggregation. However, to what extent does this mechanism contribute to the total biomass immobilization remains to be determined.

\section{Cell-Cell Attachment}

Besides the cell accumulations in carrier roughnesses, multilayers of cells were found also on flat particles and carrier 
threads (Fig. 3C). Therefore, the existence of collisions between free cells and cells already immobilized on carrier particles leading to stable cell-cell attachment can be assumed. The DLVO theory was used to calculate the changes of the interaction energy $\left(G_{\text {DLVO }}\right)$ on the separation distance between the cell surfaces (Boonaert et al., 1999). The probability of an attachment after a collision of two cells is characterized by the height of the potential barrier. The results show that the cells may be retained in a secondary potential minimum at the distance of $11 \mathrm{~nm}$ from the carrier surface (Fig. 7). However, such retention may be reversible due to the small depth of the minimum (van Loosdrecht et al., 1989). The probability of cellcell attachment in the primary minimum is enhanced by changes in the reaction environment (ethanol formation, decrease of $\mathrm{pH}$, high ionic strength) occurring during the continuous fermentation and leading to suppression of the electrostatic repulsion between cells (Stratford, 1992; Dengis et al., 1995). The decrease of the cells' zeta potential, from $-15 \mathrm{mV}$ at $\mathrm{pH} 5.0$ to $-12 \mathrm{mV}$ at $\mathrm{pH} 3.4$ (Fig. 6), diminished the potential barrier separating the cells (Fig. 7). Using an ionic strength (100 mM) common for microbial culture media (Boonaert et al., 1999) in the calculations, there was no more potential barrier to be overcome (Fig. 7).

However, the free energy of interaction between two hydrophilic brewing yeast cells (c) in water (w), calculated from the contact angle of various liquids, does not imply a stable cell-cell attachment $\left(\Delta G_{c w s}^{\text {tot }}=\sim 31 \mathrm{~mJ} \mathrm{~m}^{-2}\right)$, which is in an apparent contradiction with the microscopic observations. Therefore, as an explanation of cell-cell attachment, three mechanisms can be hypothesized, i.e., hydrophobic interactions through spatially limited hydrophobic areas on the cell surface (Gallardo-Moreno et al., 2002), flocculation, and chain formation.

The involvement of the spatially localized hydrophobic interactions in cell attachment is supported by the fact that the relative hydrophobicity of the yeast increased with time (MATH test) and that the $\Delta G_{c w s}^{L W}$ value for yeast cells in this study, from -4.4 to $-6.0 \mathrm{~mJ} \mathrm{~m}^{-2}$ (Table II), was more negative than for brewing yeast in batch culture $\sim-0.5 \mathrm{~mJ}$ $\mathrm{m}^{-2}$ (Azeredo et al., 1997). However, the presence of such regions have not yet been confirmed.

The multilayer cell immobilization on the spent grain particles can also be regarded as a flocculation. The following mechanism can then be considered. Since the electrostatic repulsion will not hinder the cell approach, at least to the secondary minimum at $11 \mathrm{~nm}$, lectins, macromolecular chains, or other cell surface appendages carrying a receptor can bind with each other, thus provoking flocculation. However, flocculation is a phenomenon that has been mostly studied in batch system while the multilayer cell immobilization onto spent grains occurs in a continuous culture. The cell physiology in these two systems is rather different, e.g., no distinct stationary phase during continuous growth, so the term "flocculation" cannot be automatically applied for the immobilization of brewing yeast onto spent grains. Assays for zymolectin would provide further information on whether the mechanism of the multilayer brewing yeast immobilization onto spent grains carrier is based only on physicochemical forces or specific (biochemical) interactions also contribute to immobilization.

\section{CONCLUSIONS}

Three mechanisms of brewing yeast immobilization onto spent grains carrier can be concluded from the presented results: cell-carrier adhesion, cell-cell attachment, and cell adsorption (accumulation) inside natural shelters on the carrier's surface.

The physicochemical aspects of brewing yeast adhesion to carrier particles obtained from spent grains were evaluated by two approaches. The calculations based on the DLVO theory showed no significant potential energy barrier that would prevent the cell deposition on the surface of the carrier. The energy balance of interfacial interactions also predicted the possibility of a spontaneous cell-carrier adhesion strengthened by hydrophobic (apolar) interactions. However, both of the approaches require simplifying assumptions and estimations. Therefore, it is imperative to avoid quantitative conclusions and to consider only trends obtained in the data.

As for the cell-cell attachment, the interpretation of the physicochemical interactions is more ambiguous. Although the DLVO theory allows close contact between cells, the interfacial interaction energy does not predict stable cellular adhesion. Therefore, other mechanisms such as flocculation, adhesion through spatially limited hydrophobic areas on the cell surface, and forced contact in shelters can also be hypothesized.

The carriers' surface roughness also contributes to the total biomass immobilization. The brewing yeasts are mechanically retained inside the shelter zones (crevices, pores, tangled threads) on the surface of spent grain particles where they can further multiply.

\section{References}

Akaiyama-Jibiki M, Ishibiki T, Yamashita H, Eto M. 1997. A rapid and simple assay to measure flocculation in brewer's yeast. MBAA Tech Quart 34:278-281.

Azeredo J, Ramos I, Rodrigues L, Oliveira R, Teixeira J. 1997. Yeast flocculation: a new method for characterizing cell surface interactions. J Inst Brew 103:359-361.

Bhattacharjee S, Elimelech M. 1997. Surface element integration: a novel technique for evaluation of DLVO interaction between a particle and a flat plate. J Colloid Interface Sci 193:273-285.

Boonaert CJ-P, Dupont-Gillain CC, Dengis PB, Dufrene YF, Rouxhet PG. 1999. Cell separation, flocculation. In: Flickinger MC, Drew SW, editors. Encyklopedia of bioprocess technology: fermentation, biocatalysis and bioseparation. New York: John Wiley and Sons. p 531-548.

Bowen WR, Cooke RJ. 1989. Studies of Saccharomyces cerevisiae during fermentation: an in vivo electrokinetic investigation. Biotechnol Bioeng 33:706-715. 
Brányik T, Vicente AA, Machado Cruz JM, Teixeira JA. 2001. Spent grains: a new support for brewing yeast immobilisation. Biotechnol Lett 23:1073-1078.

Brányik T, Vicente AA, Machado Cruz JM, Teixeira JA. 2002. Continuous primary beer fermentation with brewing yeast immobilized on spent grains. J Inst Brew 108:410-415.

Briandet R, Meylheuc T, Maher C, Bellon-Fontaine MN. 1999. Listeria monocytogenes Scott A: cell surface charge, hydrophobicity, and electron donor and acceptor characteristics under different environmental growth conditions. Appl Environ Microbiol 65:5328-5333.

Busscher HJ, van de Belt-Gritter B, van der Mei HC. 1995. Implications of microbial adhesion to hydrocarbons for evaluating cell surface hydrophobicity 1: zeta potentials of hydrocarbon droplets. Colloids Surfaces B Biointerfaces 5:111-116.

Chamberlain AHL. 1992. The role of adsorbed layers in bacterial adhesion. In: Melo LF, Bott TR, Fletcher M, Capdeville B, editors. Biofilms: science and technology. Dodrecht: Kluwer. p 59-67.

Dengis PB, Nélissen LR, Rouxhet PG. 1995. Mechanism of yeast flocculation: comparison of top and bottom-fermenting strains. Appl Environ Microbiol 61:718-728.

Domingues L, Dantas MM, Lima N, Teixeira JA. 1999. Continuous ethanol fermentation of lactose by a recombinant flocculating Saccharomyces cerevisiae strain. Biotechnol Bioeng 64:692-697.

Gallardo-Moreno AM, Méndez-Vilas A, González-Martín ML, Nuevo MJ, Bruque JM, Garduño E, Pérez-Giraldo C. 2002. Comparative study of the hydrophobicity of Candida parapsilosis 294 through macroscopic and microscopic analysis. Langmuir 18:3639-3644.

Greenspan P, Fowler SD. 1985. Spectrofluorometric studies of the lipid probe Nile red. J Lipid Res 26:781-789.

Henriques M, Gasparetto K, Azevedo J, Oliveira R. 2002. Experimental methodology to quantify Candida albicans cell surface hydrophobicity. Biotechnol Lett 24:1111-1115.

Javadekar VS, Sivaraman H, Sainkar SR, Khan MI. 2000. A mannosebinding protein from the cell surface of flocculent Saccharomyces cerevisiae (NCIM 3528): its role in flocculation. Yeast 16:99-110.

Jin Y-L, Speers RA. 1998. Flocculation of Saccharomyces cerevisiae. Food Res Int 31:421-440.

Jin Y-L, Ritcey LL, Speers RA. 2001. Effect of cell surface hydrophobicity, charge, and zymolectin density on the flocculation of Saccharomyces cerevisiae. J Am Soc Brew Chem 59:1-9.

Krishna MMG. 1999. Excited-state kinetics of the hydrophobic probe Nile red in membranes and micelles. J Phys Chem A 103:3589-3595.

Messing RA, Oppermann RA. 1979. Pore dimensions for accumulating biomass: I, microbes that reproduce by fission or by budding. Biotechnol Bioeng 21:49-58.

Mestdagh M, Rouxhet P, Dufour J. 1990. Surface chemistry and flocculation of brewing yeast. Ferment 3:31-37.

Miki BLA, Poon NH, James AP, Seligy VL. 1982. Possible mechanism for flocculation interactions governed by gene FLO1 in Saccharomyces cerevisiae. J Bacteriol 150:878-889.

Mozes N, Marchal F, Hermesse MP, Van Haecht JL, Reuliaux L, Leonard AJ, Rouxhet PG. 1987. Immobilization of microorganisms by adhesion: interplay of electrostatic and nonelectrostatic interactions. Biotechnol Bioeng 30:439-450.

Mozes N, Rouxhet PG. 1990. Microbial hydrophobicity and fermentation technology. In: Doyle RJ, Rosenberg M, editors. Microbial cell surface hydrophobicity. Washington: American Society for Microbiology. p 76-105.

Nir S. 1977. Van der Waals interactions between surfaces of biological interest. Prog Surf Sci 8:1-58.

Peyton BM, Characklis WG. 1995. Microbial biofilms and biofilm reactors. In: Hjortso MA, Roos JW, editors. Cell adhesion: fundamentals and biotechnological applications, New York: Marcel Dekker. p 187-233.

Reynolds TB, Fink GR. 2001. Bakers' yeast, a model for fungal biofilm formation. Science 291:878-881.

Rose AH. 1984. Physiology of cell aggregation: flocculation by Saccharomyces cerevisiae as a model system. In: Marshall KC, editor. Physiology of cell aggregation. New York: Springer Verlag. p 323-335.

Rosenberg M, Doyle RJ. 1990. Microbial cell surface hydrophobicity: history, measurement, and significance. In: Doyle RJ, Rosenberg M, editors. Microbial cell surface hydrophobicity. Washington: American Society for Microbiology. p 1-39.

Shankar CS, Umesh-Kumar S. 1994. A surface lectin associated with flocculation on brewing strains of Saccharomyces cerevisiae. Microbiology 140:1097-1101.

Smit G, Straver MH, Lugtenberg BJJ, Kijne JW. 1992. Flocculence of Saccharomyces cerevisiae cells is induced by nutrient limitation, with cell surface hydrophobicity as a major determinant. Appl Environ Microbiol 58:3709-3714.

Speers RA, Smart K, Stewart RJ. 1998. Zymolectins in Saccharomyces cerevisiae. J Inst Brew 104:298.

Stratford M. 1992. Yeast flocculation: a new perspective. In: Rose AH, editor. Advances in microbiology and physiology. New York: Academic Press. p 1-71.

Stratford M. 1996. Yeast flocculation: restructuring the theories in line with recent research. Cerevisia 21:38-45.

Straver MH, Kijne JW, Smit G. 1993. Cause and control of flocculation in yeast. Trends Biotechnol 11:228-232.

Straver MH, Kijne JW. 1996. A rapid and selective assay for measuring cell surface hydrophobicity of brewer's yeast cell. Yeast 12 : 207-213.

Suzzi G, Romano P, Vannini L. 1994. Cell surface hydrophobicity and flocculence in Saccharomyces cerevisiae wine yeasts. Colloids Surfaces B Biointerfaces 2:505-510.

van Hamersveld EH, van Loosdrecht MCM, Luyben KCAM. 1994. How important is the physicochemical interaction in the flocculation of yeast cells? Colloids Surfaces B Biointerfaces 2:165-171.

van Loosdrecht MCM, Lyklema J, Norde W, Zehnder JB. 1989. Bacterial adhesion: a physicochemical approach. Microbiol Ecol 17:1-15.

van Oss CJ, Chaudhury MK, Good RJ. 1988. Interfacial Lifshitz-van der Waals and polar interaction in macroscopic systems. Chem Rev 88: 927-941.

van Oss CJ. 1995. Hydrophobicity of biosurfaces: origin, quantitative determination and interaction energies. Colloids Surfaces B Biointerfaces 5:91-110.

Vernhet A, Bellon-Fontaine MN. 1995. Role of bentonites in the prevention of Saccharomyces cerevisiae adhesion to solid surfaces. Colloids Surfaces B Biointerfaces 3:255-262.

Vicente AA, Meinders JM, Teixeira JA. 1996. Sizing and counting of Saccharomyces cerevisiae floc populations by image analysis, using an automatically calculated threshold. Biotechnol Bioeng 51:673-678. 